Administrative Issues Journal: Connecting Education, Practice, and Research, Summer 2019 Vol. 9, No. 1: 01-18. DOI: 10.5929/9.1.6

\title{
Executive recruitment triads from an agency theory perspective
}

\author{
Carlos Baldo, Ph.D. \\ Colorado Mesa University \\ Ramón Valle-Cabrera, Ph.D. \\ Universidad Pablo de Olavide \\ Miguel Olivas-Lujan, Ph.D. \\ Clarion University of Pennsylvania
}

\begin{abstract}
The relationships between clients, headhunters, and candidates during the executive search process has not been researched using agency theory as the theoretical framework. This is puzzling, as the existence of common objectives and information asymmetries between these three parties make agency theory an ideal one to explain the interactions between them. We addressed this gap by developing six testable propositions for researchers. Practitioners may also benefit from the study as understanding the human assumptions in the process of executive recruitment may help increase the chances of achieving positive outcomes.
\end{abstract}

Keywords: Executive Recruitment, Agency Theory, Headhunters, Triad, Information Asymmetries

\section{Introduction}

$\mathrm{n}$ recent years, talent has become a strategic priority for organizations (Guthridge, Komm, \& Lawson, 2008). The "war of talent" (Faulconbridge, Beaverstock, Hall, \& Hewitson, 2009) is at the top of the business agenda as organizations look to attract the most talented executives to lead their businesses. The complexity of this process among the core activities for strategic HR has led to the outsourcing of talent recruitment and selection ${ }^{1}$ (Greer, Youngblood, \& Gray, 1999). For high-level executives and many other highly skilled employees, the responsibility is shared with third parties that provide recruitment, selection, and onboard services. Within the professionals' or practitioners' field, these firms are also known as Executive Recruitment Firms or Headhunters.

Executive recruitment refers to the process of attracting and selecting candidates through direct and personal contact by a specialist consultant who acts as an intermediary between the employer (often referred to as client or customer) and the candidates for the available position (Britton, Wright, \& Ball, 2000). An industry report by the Association of Executive Search Consultants (Association of Executive Search and Leadership Consultants (AESC), 2014) forecasted that these service providers would generate

\footnotetext{
${ }^{1}$ we want to clarify to readers that throughout the paper we use Recruitment and Selection (R\&S) indistinctly. Some academics and practitioners may argue that this is a different process, and we totally agree, but we generate enough information in the paper showing that headhunters may be involved in both R\&S activities, therefore, the term should be understood within the scope described.
}

BALDO, VALLE-CABRERA \& OLIVAS-LUJAN / DOI: 10.5929/9.1.6 
around $\$ 11$ billion in 2014 , showing a steady growth of revenue since 1978 . The same report also detailed high expectations in maintaining growth for this industry, mainly due to demographic shifts in developed countries. Considering these socio-economic facts and their role in providing highly qualified, hard-to-find talent for organizations, the importance of research on this topic cannot be overstated.

Clerkin and Lee (2010) highlighted the scarcity of research on the executive search process. Theories like Transaction Cost Theory (Williamson, 1981), resource base view (Barney, 1991), and coordination theory (Malone \& Crowston, 1990) have been applied in the few studies done on this topic. Transaction Cost Theory frames headhunting as outsourcing (Finlay \& Coverdill, 1999) while resource base view explains why young companies poach executive talent from competitors (Rao \& Drazin, 2002) and coordination theory helps to understand the expectation gaps between the intervening parties (Britton et al., 2000).

Another perspective that sheds light on the executive search process is agency theory (Jensen \& Meckling, 1976), which explains cooperative efforts between organizations and agents (Eisenhardt, 1989), such as executive search firms (ESF). This cooperation, in part, is the information exchange. Information is considered a commodity that may be exchanged for money; thus, in the recruitment process, there is a knowledge imbalance between the three parties: client, headhunter, and candidate. This imbalance is known in agency theory as information asymmetry (Stiglitz \& Weiss, 1992), which may be defined as the dissimilarity in knowledge between two parties in an economic or social interaction with respect to outcomes (Shapiro, 2005).

While other theories explain why companies use headhunters, coordination and agency theories are more concerned with what happens during the process. Unfortunately, coordination theory assumes common goals between the intervening parties; an assumption that, as we show below, does not always hold true. Agency theory reflects this and offers robust explanations of behaviors exhibited by the parties in this triad: clients, headhunters, and candidates. A triad can be defined as an exchange that involves three parties: buyer-intermediaries - seller (Simmel, 1964). Typically, agency theory has been used most often to explain dyadic relationships, but we submit that using it in the context of this triad is a contribution to the field.

There are two main purposes of this paper. First, we discuss the applicability of agency theory in the context of this triad. Second, to study this triad, we use examples documented in the context in which information asymmetries play an important role. In addition, we present testable propositions to demystify this process. A key contribution is a theoretical discussion about what happens during the executive search process using headhunters, which gives partial explanation to the argument posed by Sengupta (2004), that there are so many companies (headhunters) that are able to assess potential candidates reasonably well, but are unable to reach the matchmaking with their customers.

The structure of this paper is as follows. In the first section, we review agency theory in the realm of recruitment and selection of executives using headhunters. We examine a triadic instead of the traditional dyadic process. Next, we review the headhunter's role and the payment schemes used with possible effects on the process. The third part elaborates on information imbalance from the candidate's angle. To conclude, we present implications, conclusions, and potential areas for future research.

\section{Agency Theory and Executive Search Firms}

Agency theory can be defined as a mode of interaction between two (or more) parties, where the agent is hired or appointed to make decisions on behalf of the principal (Ross, 1973). This concept has been used to describe the interaction between the headhunter and the client or employer (Britton \& Ball, 1999). The theory focuses, in part, on how information differences or asymmetries (Akerlof, 1970) may affect goal

BALDO, VALLE-CABRERA \& OLIVAS-LUJAN / DOI: 10.5929/9.1.6 
alignment between principal and agent (Eisenhardt, 1989). This situation is commonly present in many employer-employee or client-vendor relationships.

These asymmetries between principal and agent can lead to two main situations: moral hazard (Arrow, 1963) and adverse selection (Akerlof, 1970). Moral hazard can be conceptualized as the benefit extracted from taking advantage of another, using information from related interactions (Holmstrom, 1982). In some cases, either party's partial or total ignorance may augment asymmetry. Moreover, the eventual discovery of the advantage may terminate the relationship (Baker, 1996). Adverse selection describes situations when, due to the information imbalance, the principal is not fully aware of the quality of the service or product offered or chosen by the agent. Therefore, the decision may produce undesirable results (Akerlof, 1970).

Britton and Ball (1999) used agency theory to describe the client-headhunter relationship. Clark (1993) used information asymmetries and the potential outcomes (moral hazard and adverse selection) to explain quality in service industries. Due to the intangibility and perishability of the services, information asymmetries exist because service providers (including headhunters) may be able to offer high- or lowquality products, but the buyer is unable to fully assess the value of such characteristics. However, while Britton and Ball's (1999), and Clark's (1993) papers were pioneering in using agency theory to study ESFs and their clients, the candidate's role, which is arguably the most important actor in the process, was not included. Their agency perception is just based on the natural agency figure (dyad) between clients and ESFs, or two parties. They did not indicate the double agency issues that appears to include the candidate (triad).

Research in agency theory has considered situations in which the agent has responsibilities with two principals who may interact between them (Hallock, 1999). Dual agency is defined as the condition in which an agent has two sets of controls or principals (Child \& Rodrigues, 2003). The agent, thus, may compromise the level of trustworthiness between each party, creating potential conflicts of interest. In other words, the dual agent has responsibilities to both parties. Dual agency has been used in service sectors, like real estate (Evans \& Kolbe, 2005; Heisler, Kallberg, \& Liu, 2007; Miceli, Pancak, \& Sirmans, 2000), where the relationship between sellers, realtors, and buyers - another triad-is scrutinized. Other researchers also mention dual agency in relation to corporate board compositions and governance (Child \& Rodrigues, 2003; Hallock, 1999) and psychiatrists in the military (Hines, Ader, Chang, \& Rundell, 1998).

The basic perception of a triadic relationship among intermediaries in the labor market has been identified (Bidwell \& Fernandez-Mateo, 2008). However, Bidwell \& Fernandez-Mateo use the context of temporary employment agencies. These are intermediaries, which provide staffing contracting services. We argue that this notion defers from our paper position because, in their case, the control and power rely on the principal (a company which hires the staffing agency) and agent (staffing agency); the workers have a minimum in the control and power distribution.

In this case, the Agency situation is like that in a supply chain as context. For instance, Gunawardane (2012) and van der Valk and van Iwaarden (2011) have studied service triads in the context of supply chains and construction. Using agency theory in the headhunter's context is, therefore, a logical extension with highly valuable implications.

Agency theory presents human and organizational assumptions that permeate the theory (Eisenhardt, 1989); the human assumptions are:

- Self-Interest: individuals tend to give priority to their own benefits, even when they are performing on behalf of someone else (Smith, 2010). Also, in the case of executive recruitment,

BALDO, VALLE-CABRERA \& OLIVAS-LUJAN / DOI: 10.5929/9.1.6 
the individualistic culture (Miller, 1999) related to career advancement for the candidates, possibility to fulfill job order (search) by the headhunter, and locating the right candidate in the adequate timeframe and salary by the client makes this self-interest play a preponderant role during the relationship engagement among all parties.

- Bounded Rationality: decisions made by individuals are based on incomplete information; in many cases, the decision is not optimal (Simon, 1957). This is the core issue in this relationship. First, this bond is based on initial information asymmetries among the parties. Second, because the information is partially disclosed during the process. And finally, as all information is disclosed, it does not necessarily imply that the client chose the optimal candidate, or that the candidate accepted an equal or better than expected position.

- Risk Aversion (Arrow, 1965): individuals tend to take less risk in decision making if a potential outcome has a negative level payoff.

Eisenhardt (1998) mentions the following as organizational assumptions:

- Partial goal conflicts among parties: both principal and agent interests are based on the human assumptions described above. Thus, whether they engage in a contract or not, their ultimate interest may be different.

- Efficiency as the effectiveness criterion: in other words, the selection of the governing contract for the relationship may be based on behavior (process) or outcome (result). Actors will choose whatever contract is the most efficient for their interaction.

- Information asymmetry between the parties: from the beginning, the principal engages with the agent assuming the latter has better knowledge about the particular task; thus, asymmetry is embedded.

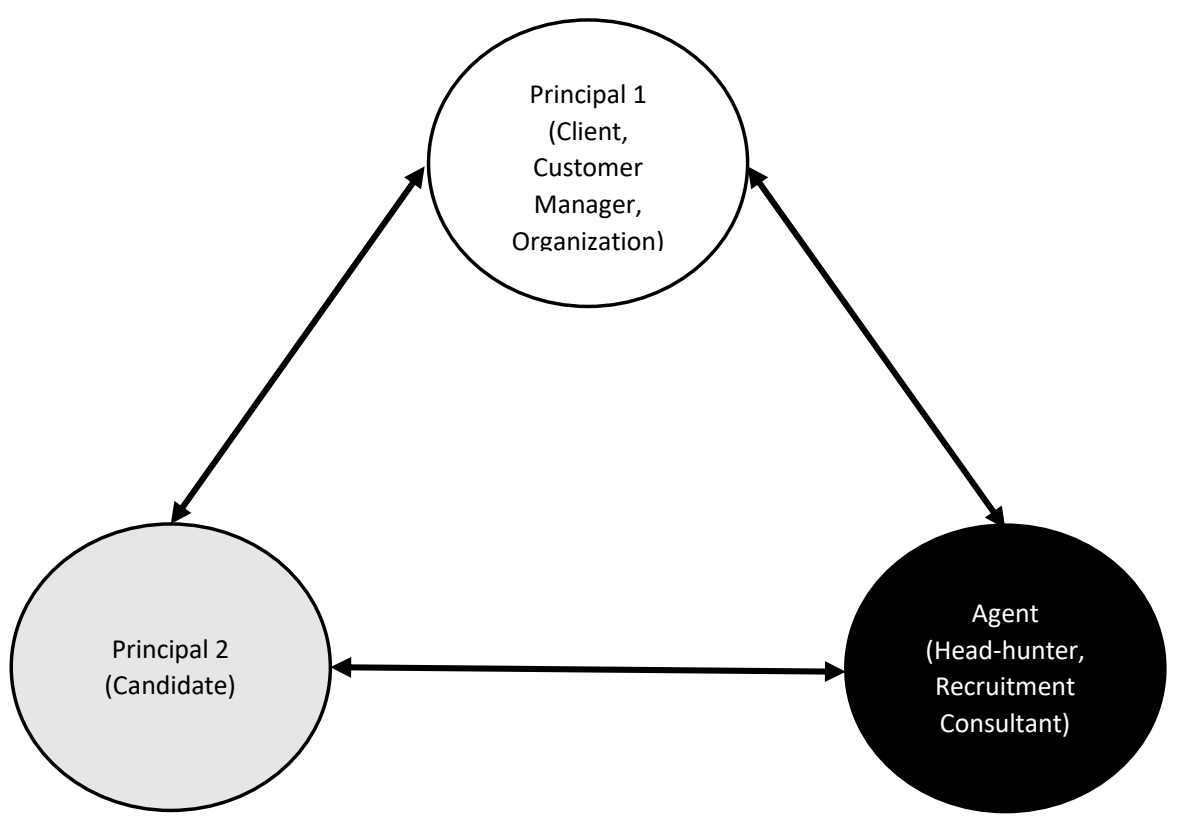

Source: own elaboration, based on Eisenhardt, 1989 and Britton, Wright \& Ball, 2000.

Figure 1. Relationship between customer-headhunter-candidate from a double agency perspective. 
Each of these assumptions is present in the headhunting process. Figure 1 shows the interactions in the triad. For instance, research by Coverdill and Finlay (2000) described the low level of risk taken by headhunters to secure job orders from customers. They describe how final goals for intervening parties are different: for the client, the goal is to obtain a suitable candidate and for the headhunter the goal is to provide service with the possibility of repeating business. In relation to human assumptions between headhunters and candidates, Luci (2012) discussed how interactions may benefit headhunters and clients, (for instance, knowing the salaries in the labor market). Therefore, we consider that a distinguishable contribution to this study is to be able to connect these two dyads (client- headhunter and candidateheadhunter) and see them as a "triad case" (client-headhunter-candidate), not only based in the transactional, short-term, but also in the relational long-term.

\section{Headhunters, Information Asymmetries and payment schemes}

Executive search firms can also be characterized by specialization, such as information technology, marketing and human resources (Garrison, 2005). Other headhunter characteristics are that they provide efficiency and expertise-based advantages (Hamori, 2004). In relation to efficiency, headhunters tend to have databases with sizable pools of potential candidates for executive positions or experienced individuals with rare competencies. They are then able to expend less time and resources than most human resources units. Their duties include all the tasks needed to have a positive outcome. For instance:

prescreening candidates according to the criteria define by the client, provide access to a larger pool of potential candidates who otherwise may not be interested, promote the client firm to candidates or groups, diffuse incorrect or potential damaging information, and serve as channel of communication during the recruitment and selection process between client and candidates. (Africa \& Major, 1988)

In some cases, they are chosen by clients to execute "lateral" hiring (Gardner, Stansbury, \& Hart, 2010), which is also known as "poaching" candidates from competitors.

The service quality generated by headhunters (as many other consultants) is ex-post, when the candidate gets hired and their performance can be measured. Thus, to provide early quality signals to their clients, headhunters engage in some forms of dramaturgy that indicate the value they will offer (Clark \& Salaman, 1998). These early signals are important elements that explain the trust-based relationship between executive recruiters and clients (Werr \& Pemer, 2007).

Another justification for using an external source is based on Transaction Cost Theory. Considering the low frequency of an executive search process and how the newly hired employee's competencies are so rare, organizations prefer "buying" talent instead of "making" it (Williamson, 1981). In some cases, it is costlier to develop within the company a replacement for a leadership position than to bring in a good candidate from the outside (Finlay \& Coverdill, 1999). Besides the economic reasons, there are other reasons why companies may use headhunter, for instance, to legitimize the selection of a candidate for an upper echelon position when stakeholders require an external search (Khurana, 2002).

To understand the triangular relationship, we describe how this process happens. Some authors (Finlay \& Coverdill, 2002; Garrison, 2005; Jones, 1989) agree on the general features of the recruitment process using headhunters. First, the client requests candidates with a particular profile from the consultant. These candidates must have a set of skills and competencies that satisfy the client's expectations. Next, the consultant will prioritize the search for those candidates in their database and network of contacts. Those candidates who match the desired profile may be interviewed and screened about the position; then those open to the possibility of working for the client will be included in a "short list" of potential

BALDO, VALLE-CABRERA \& OLIVAS-LUJAN / DOI: 10.5929/9.1.6 
candidates. Following contractual conditions, the consultant will then present a short list with candidate dossiers. With this information, the client evaluates potential fit and proceeds to interview those candidates whom they deem best. Once the client recognizes their most desirable candidates, they proceed to make an offer. If accepted, the candidate initiates the client's internal recruitment process or onboarding. At this point, the consultant may monitor only the culmination of the process; but, in some cases, they may help with the onboarding (a process by which organizations help new employees adapt to their new positions in an organization).

Finlay and Coverdill (2002) said that headhunters have to make a "Double Sale": candidates to their customers and vice versa. This can be perceived as an early notion of dual agency; however, their approach leaned more into how imperative it was to the headhunters to complete the search, and not in the agency's perspective. In other words, find the right candidate from the client perspective, and that this candidate accepts the job offer. These roles are similar to those of brokers, with the major difference being that their "products" - candidates and clients - can share information or keep it to themselves. Headhunters act as "Tertius Gaudens," or "happy third parties" (Simmel, 1964), capitalizing on the interaction between client and candidate and ideally placing them in a better position by putting buyers and sellers in the same context. This headhunter brokerage allows them to act as an agent for the candidate (as well as the client), therefore, triggering what we defined in the previous section as "Double Agency." This moment is the trigger for an increase in information asymmetries between the three parties.

Towards the end of the process, the headhunter is described as the "Visible Hand" (Finlay \& Coverdill, 2002) and often acts as a mediator between the other two parties. Each step of the search process, involves an information-like sharing process that involves getting information from clients and candidates, selecting likely candidates, interviewing and ensuring offers are made, asymmetric information and moral hazard may become an issue. These issues may be reduced, increased or modified based on each executive search firm's contractual and other preferences.

Agency theory research (Eisenhardt, 1989) emphasizes how important it is to review the payment scheme used in the process. Dingman (1993) divides headhunters into two big groups: "Retainers" and "Contingents." Retainer search firms are those that charge a periodic fee and often have exclusivity during each of the sub-processes of the search. The exclusivity and the intention of keeping customers, in the end, constitute incentives for seeking optimal results, i.e., finding the best available candidate to suit customer requirements.

"Contingency recruiters" are those firms that only get paid if the position is filled successfully (Garrison, 2005); their fees are totally dependent on their outcome. These headhunters do not receive exclusivity in their search and they may be competing with other firms also performing a search for the same client (Finlay \& Coverdill, 2002). These types of recruiters tend to perform searches for mid- to low-level positions compared to "retainer headhunters," who aim for higher level positions. Regardless of the differences between the two groups, we posed similarities for our claims in this paper.

Considering agency theory's organizational assumption of efficiency in the selection contract type, contingent headhunters are almost solely based on outcomes, while retainer headhunters are rewarded by a mix of the outcomes and behavior (processes) that they deliver and exhibit. These claims are related to the arguments presented by Eisenhardt (1989) describe among the organizational assumptions, clients will choose the type of headhunter that match their needs.

This situation is consistent with a report published by Bullhorn Inc. (2014) (Software company focused on

BALDO, VALLE-CABRERA \& OLIVAS-LUJAN / DOI: 10.5929/9.1.6 
$\mathrm{CRM}^{2}$ solutions for headhunters) that suggests that "retainers" do searches faster than "contingents." Also, retainers complete more assignments than contingents. This is also in line with a report by the Association of Executive Search Consultants, in which they compared the benefits between retainer and contingent headhunters. The capacity demonstrated by retainer headhunters regarding the process, the speed, the quantity of searches provided, and, most importantly, long term relationships with their customers, leads us to believe that they tend to manage information asymmetries better. More evidence that may be considered to support the idea of reduced information asymmetries by retainer headhunters can be how best firms are rated. The most influential headhunters (Bloomberg Business, 2008a; Bloomberg Business, 2008b) and more important firms (Garrison, 2005) tend to be retainers. We argued that retainer firms relapse on their quality recognition in using this payment scheme, and their results tend to satisfy their clients, consequently reducing information asymmetries with them. Therefore, we present our first set of testable propositions:

\section{P.1a Executive recruitment searches using retainer firms exhibit reduced information asymmetries.}

\section{P.1b Executive recruitment searches using contingent firms exhibit increased information asymmetries.}

\section{Timeframe}

These propositions leave open the possibility that retainer firms may also manage unbalanced information and can generate morally hazardous situations. For example, the time to deliver results is an important indicator in this industry (Bullhorn, 2014). Based on the urgency to fulfill the position, the client and headhunter should define an initial time frame. Previous research has reported the importance of time to produce results as a quality element expected by clients (Fish \& Macklin, 2004). We also suggest that knowing how urgently services are required is consistent with the human assumptions of the theory; this time frame can be used by headhunters or candidates to extract rents from the client.

For instance, the headhunter's self-interest may afford higher priorities to a particular search. Also, adding rationality, the urgency of the position to be filled may impose larger constraints on the decision-making process. Ultimately, the headhunter may exhibit different behaviors to manage the situation. For instance, if the period is short, the headhunter could produce candidates with a lesser likelihood of person-position or person-organization fit than if they took more time to identify candidates. This argument diverges from Kristof-Brown et al. (2005), in which they argued that recruiters' perceptions of candidates' personorganization fit are low in validity. However, our position is aligned with evidence presented by Carless (2005), in which she advocates for the need of more information early in the recruitment process to develop better fit perception, and, therefore, with more time, the headhunter may develop a better person-position fit. As quality in the person-position fit is likely a function of information shared, consequently the agent (headhunter) is not able to execute the task with the quality required by the principal due to constraints indicated by the latter. We now offer our second proposition:

\section{P.2 Executive recruitment searches with defined or longer periods for execution reduce information asymmetries.}

\footnotetext{
${ }^{2}$ Customer relation management can be defined as a data base management tool that allows for increase in customer retention or customer partnering (Sin, Alan, \& Yim, 2005).
}

BALDO, VALLE-CABRERA \& OLIVAS-LUJAN / DOI: 10.5929/9.1.6 


\section{Confidentiality}

Fish and Mack (2006) considered the high importance of confidentiality in the headhunting process. In fact, confidentiality is of high importance in managing information from client firms to candidates and vice versa, when acting as messengers, buffers, and mediators between them. By itself, the term "confidentiality" implies unbalanced information. Indeed, this has been a major limitation to carrying out research in this industry. Moreover, under the veil of confidentiality, not all interactions are honest (Jamal \& Bowie, 1995). We may argue that, in some cases, the actors in the process use this confidentiality as a shield to limit access to information. Therefore, this confidentiality may have positive or negative consequences during the executive recruitment process.

Confidentiality towards the candidates harms the process in many cases. Volpe and Tucker (2004) stated how limiting the information given to the potential candidate may hamper the evaluation of whether a position is desirable to them or not. A second scenario could be that the consultant gives excessive information that allows the candidate to negotiate from a stronger position, opening the door to opportunistic behavior or moral hazard. A third scenario would be when the consultant creates false expectations in the candidate, and the latter makes decisions (e.g. resigning from present job) without a firm commitment from the hiring client (adverse selection). On the other hand, in some instances, those levels of confidentially may not even exist in search processes in which full transparency may be required. For example, some searches in education, nonprofit organizations, or a few government agencies cannot guarantee confidentiality due to regulations or organizational preferences.

Headhunters may produce a better way to process the candidates if they provide precise and clear information about their clients, similar to what has been called realistic job previews (Breaugh, 1983), ${ }^{3}$ but they should always strive to maintain the client's confidentiality if requested (National Association of Executive Recruiters, 2014). The problem with confidentiality is that the agent must maintain such condition of non-disclosure to keep alignment with the principal. However, at some point, whether or not an agent adheres to confidentiality can compromise delivering results on the conditions predefined by the parties. These situations indicated by us diverge with those described in the law's practice; this suggests that lawyers who mediate between two other parties, having information that may benefit one of them, should opt out in the mediation (Dzienkowski, 1992). In our situation, at least from the headhunter's point of view confidentiality is negative, because dropping the search may limit business; and future job offers. We introduce our third proposition:

\section{P.3 Executive recruitment searches with high levels of confidentiality may lead to moral hazard and/or adverse selection by the parties involved.}

We have presented some situations that show how information asymmetries can be originated by headhunters. However, this relationship still has two other members in this triad. We now turn to a discussion of how clients' actions also affect the process.

\section{Information Asymmetries created by client firms}

Clients play a very active role in the triad. Based on the report published by the Association of Executive Search Consultants in $2011,68 \%$ of their customers have an in-house unit that may perform recruitment and selection processes, usually the HR or personnel department. Their client firms are in multiple

\footnotetext{
${ }^{3}$ Realistic job preview (Premack \& Wanous, 1985) can be defined as all positive and negative information in regards to a position that employers provide to potential candidates.
}

BALDO, VALLE-CABRERA \& OLIVAS-LUJAN / DOI: 10.5929/9.1.6 
industries or sectors, as well as in multiple countries (Faulconbridge, Hall, \& Beaverstock, 2008).

A common denominator for many organizations that hire executive recruiters is the partial or complete failure of succession planning (Byrne, 1986; Khurana, 2001; Khurana, 2002). Succession planning has been defined as the leadership developing internally within an organization to guarantee that there will be people for the upper-echelon positions in the future (Charan, Drotter, \& Noel, 2010). Many times, headhunters are contacted by customers when there is an urgent need for a replacement.

In some cases, headhunters are called to perform searches because of conflicts of interest between clients and their current employees. Third parties may be the best choice for protecting the clients' interests (Sengupta, 2004). To illustrate, a position may be covered, but the company may try to find a more suitable replacement, in cases like new marketing officers or positions related to changes in the business model. A company that is changing its strategy may realize that current employees lack the necessary knowledge, skills, and attributes for its new direction; however, companies may decide to maintain or retain someone even if a replacement is hired. Another example is when a technical or leadership position that requires high levels of confidentiality towards any stakeholder opens. Many companies attempt to manage the process outside the organization. In all cases, the main information providers are the clients.

What is clear is that client firms are generally responsible for initiating the process by giving the "job order" (Finlay \& Coverdill, 2002). Qualitative research by Hamori (2002) addressed three roles of "clients" during an executive search process using third parties. She argued that there are three important roles played by client firms: ultimate decision maker, executor of the search steps, and input (information) provider. In the first role, ultimate decision maker, clients are the ones responsible for choosing among the candidates shortlisted by the headhunter; the client's decision will override any of the headhunters' suggestions.

In the role of executor of the search, Hamori (2002) describes how clients manage the interview process. They have control of this situation. In some cases, the headhunter may try to influence candidates, but clients will be the ones that will ultimately make the candidate confident about this potential outcome (staying in the process and eventually accepting the position). Finally, as an input provider, the client provides continuous feedback regarding the candidates and services rendered. For instance, in providing feedback about candidates after the first interviews, the client lets the headhunters know how suitable the candidates were. Furthermore, at the end of the service, input is given. This may correct any potential mistakes for further searches.

\section{Ideal candidate profile}

Input from the client (once the process is closed) may help the candidate's onboarding process, avoid early termination or reduce turnaround in the position. We submit that the information provider is a decisive role for the client, because, if the information given to the headhunter and the candidate is limited or unclear, information asymmetries will be increased. Therefore, the headhunters' duties are beyond the short-term, transactional relationship. In other cases, the headhunter may have to exert extra effort due to limited information from the client. For instance, the principal might not provide enough information about the skill set the ideal candidate should have (Williamson, Wachter, \& Harris, 1975).

The ideal candidate profile includes three characteristics. Two have already been developed by Finlay and Coverdill (2002): Knowledge, Skill, and Attributes (KSA), and fit. KSA, or specifics, are the technical characteristics that give evidence to the employer that the candidate will be able to perform the task; they are usually defined in the job profile. The fit (Rynes \& Gerhart, 1990) is a form of adaptability that the ideal candidate will have in order to adjust to the organizational culture of the client's firm and to the

BALDO, VALLE-CABRERA \& OLIVAS-LUJAN / DOI: 10.5929/9.1.6 
particular job. In both cases, these factors are measurable. However, we also consider that there is a portion of this ideal candidate's profile often not provided by the client; what has been defined as the "Hidden Profile" concept developed by Baldo (2014). This includes all the client's biased perceptions about a group of candidates who may have a specific race, gender, education, etc. These are not usually disclosed by the client, but by "screening" so that the headhunter may be able to identify them before presenting candidates.

This information is vital to creating a narrower and more precise shortlist of candidates. Williamson et al. (1975) argued that not being clear about an ideal candidate's characteristics may trigger a moral hazard from the agent, because the headhunter will know how complicated the task will be and, consequently, he or she will find justification to increase the price of the service. The partial disclosure of information may happen consciously or unconsciously. However, it may also open the door for opportunistic behavior by the client firm, because its managers may use the lack of information to blame the headhunters if the process fails. More formally, our fourth proposition states:

\section{P4: Executive recruitment searches that have an extensive ideal of a candidate's profile reduce information asymmetries.}

\section{Employment Status for Recruiters}

For many companies, the employment status (employed or not) is an important factor during the recruitment process. For instance, employers tend to consider candidates to be more suitable if they are employed (Eriksson \& Lagerström, 2006) at the moment that they are contacted by the headhunters. Clients can also use information created by other parties to generate an opportunistic situation. Previous research (Behrenz, 2001) has shown that many candidates are employed at the moment they engage in an executive recruitment process using third parties. However, in some cases, this employment status may generate information asymmetries between the client firm and potential candidates. Specifically, when a candidate is employed, he or she may be more averse to the risks associated with considering other jobs. On the other hand, unemployed candidates may be more collaborative during the executive search process, because they do not have the safety net or the reputational risk that employed candidates have.

Based on this mobility, we argue that, at times, the best candidate may not be found in other organizations but in the labor market. Mergers, acquisitions, or other similar events may cause perfectly effective and productive individuals to experience a spell of unemployment. Other candidates may leave their employers because of reasons not related to the executive's reputation, or their organization's performance. Regardless of the reasons, it is conceivable that very suitable candidates may be temporally unemployed. As such, unemployed candidates may be more collaborative during the process, for instance, engaging with the headhunter and the client. This is aligned with agency theory because the risk aversion for an unemployed candidate is lower due to the self-interest in obtaining employment. However, from the client's perspective, unemployed candidates are underappreciated because they may send the wrong signal to potential employers.

Employment status can create opportunistic behavior from the client firm as well. For example, clients may offer compensation below the originally expected salary. When clients do not mind the candidate's employment status (employed or not), the process tends to be less asymmetric for all the parties involved. Clients can expand the potential pool of candidates. Agency theory suggests that a salary offer below the one originally disclosed by the headhunter can generate moral hazard on the client's part and a bad beginning for the relationship between the employer and the employee. This may be minimized if a

BALDO, VALLE-CABRERA \& OLIVAS-LUJAN / DOI: 10.5929/9.1.6 
preliminary salary is included in the realistic job preview disclosed by the executive search firm to the potential candidate.

This gives rise to our proposition:

\section{P.5 Executive recruitment searches that include unemployed candidates reduce information asymmetries with the headhunter but increase the asymmetries with the client's firm.}

We now present a candidate's perspective on the ongoing problem.

\section{The Candidate's perspective}

The candidate can be considered the product or service that the headhunter offers, while his or her placement is the outcome. However, there are important characteristics that a candidate needs that can influence the outcome. Finlay and Coverdill (2002) call these "Hot Buttons." They use this term to refer to specific skills and experiences that create positive signals for future employers. These include a high level of managerial knowledge and knowledge of the nature of the organizations. Mobility from one organization to another, whenever required (Murphy \& Poist, 1991), is also an important characteristic. Candidates should have portability of their knowledge, skills, and abilities (KSA) and not be specific to their current organization (Groysberg, Sant, \& Abrahams, 2008). Another characteristic is adaptability, falso called adjustment by Coverdill and Finlay (1998). Even if the skills are of vital importance, this flexibility is a must; it has a high weight among the characteristics of potential executive candidates. Customers will choose candidates who can bring from their previous assignments qualities that have enabled them to be high performers. Such characteristics are expected to allow them to replicate past successes in a new organization with a different set of circumstances.

Independent of the candidate's characteristics emphasized by Hamori (2010) or the particularities of some candidates described by Garrison (2005), what makes candidates homogeneous is that they are human beings. Therefore, they are more likely to exhibit the human assumptions described by Eisenhardt (1989): self-interest, bounded rationality, and risk aversion. These can be more transcendent and decisive in a triad context, because the candidate may use the safety net (easily marketable in the executive market) provided by his or her characteristics (high level of education, network, tenure, previous experience with well-recognized organizations and international exposure (Hamori, 2010)) to obtain additional benefits in the search process.

Candidates may also try to assess their market value as a potential candidate by participating in a search process just to receive an offer and eventually use this as leverage to renegotiate with their current employer (Finlay \& Coverdill, 1999). Or candidates may refuse to continue the search process regardless of the economic impact (usually a significant, positive increment in income). Moreover, candidates can use their knowledge of an intention to quit (self-interest) to engage in an executive search process that may be time-consuming (bounded rationality). The potential candidate pursues the relationship with the others (headhunter and client), even with the possibility of losing their current employment due to lack of commitment with the existing employer (risk aversion). Intention to quit can be defined as the perception of probability felt by an individual to leave the present employer in the short future (Vandenberg \& Nelson, 1999). Unfortunately, due to the nature of the process, the creation of a false potential candidate is possible, which may jeopardize future services with the client firm. Therefore, it is almost imperative that the headhunters reduce or eliminate this type of candidate from the pool and shortlist because they do not have goals aligned with the headhunter.

We may also argue that in some cases, due to excessive information sharing between candidate and client,

BALDO, VALLE-CABRERA \& OLIVAS-LUJAN / DOI: 10.5929/9.1.6 
the first one may take advantage of the situation. Networks in the world of executives have become an important aspect to consider when choosing candidates: "As a manager moves into a leadership role, his or her network must reorient itself externally and toward the future" (Ibarra \& Hunter, 2007). These networks or connections may play an important role in the candidate's outcome during the recruitment process using headhunters. This access to information through networks can be highly valued for career success (Seibert, Kraimer, \& Liden, 2001). We contemplate that this career success in the context (clientheadhunter-candidate relation) is related to obtaining a higher salary in a new job venture. This argument is anchored in previous research done on this topic, For instance, proactive people tend to have career initiative, which is positively related to salary progression (Seibert, Kraimer, \& Crant, 2001). Individuals who use sponsor mobility (using others to change jobs) tend to obtain higher salaries (Ng, Eby, Sorensen, \& Feldman, 2005).

Therefore, it can be in the self-interest of a candidate to bargain for a greater salary offer, even if that compromises staying in the search process with the headhunter (bounded rationality), risking a salary offered which is higher than his actual but lower than the expected through the information managed. For example, if the candidate knows through his or her network any privileged information about the client, the candidate may use this as a bargaining tool to negotiate the initial offer. In a situation like the one previously described, there is a clear possibility that moral hazard will appear.

We now present our sixth proposition:

\section{P.6 Executive recruitment searches using only employed candidates increase information asymmetries with the headhunter.}

\section{Implications and Conclusion}

Considering agency theory and the human assumptions mentioned by Eisenhardt (1989) discussed in this paper, we propose a different perspective on how to understand the process or interactions between these parties. Perhaps this paper can answer the question posed in the introduction by Sengupta (2004) about why many executive search processes are not successful. The answer may rely on the analysis of these interactions in which all parties initially may have similar goals, but in reality, have different agendas. We posed that headhunters, in many cases, think that just because a candidate may be a good fit for their client does not necessarily mean he or she is the best candidate for said client. Another possible answer to Sengupta's question may rely on the headhunter's superior knowledge of the client's needs. A good way to increase this knowledge is by reviewing past searches to highlight best practices and common characteristics for further candidates. Finally, in the same line, clients must understand that a long-term relationship with headhunter may boost the possibility to produce better results.

We consider it important to note that this triad relationship (an exchange that involves three participants) tends to be long-term (relational), therefore, double agency allows theoretical research along this line. For instance, for the headhunter, maintaining a long-term relationship with a customer is the key factor. Also, headhunters may see any potential candidate as a potential customer. Moreover, clients may try to engage in a long-term relationship with headhunters that produces positive results. For instance, it is more likely that when a headhunter provides a service as expected, the headhunter develops a better sense of the kinds of individuals that their clients may be looking for. Another important aspect is to open a discussion about whether retainer or contingent payments provide better solutions, and if so, in what ways. This has important implications for the practitioner community.

Understanding the described triadic relationship is key for the reader. Each party involved in the process has power, control, and weight in the goal. Thus, the relationship should be analyzed as a triad, and not

BALDO, VALLE-CABRERA \& OLIVAS-LUJAN / DOI: 10.5929/9.1.6 
as two sets of dyads as other theoretical frameworks have done.

This paper addressed time frames in the search process. We understand that our position may contradict some traditions in the executive search firm's industry. However, the timing issue is one that warrants further discussion in this sector.

In considering the "ideal candidate" profile in an executive search process, anecdotal evidence from practitioners argues that there are no tried and true methods for determining this. Conversely, we posit that this issue plays a part in simplifying information asymmetries during the process, thus increasing the information sharing between client and headhunter. Perhaps in narrowing down what could be considered an ideal candidate's profile, information imbalances between all parties could be reduced substantially. However, this could jeopardize the headhunters' role. For instance, if clients found new methodologies by which to reach ideal candidates, in theory, the numbers of searches using headhunter could be reduced.

It seems that the big distinction between a candidate's employment status during the process could be a topic for further analysis by practitioners and researchers, especially when considering the role of ethics. For instance, we argue that clients could use headhunters to discriminate against some individuals, due to their employment status or the "hidden profile" mentioned before.

Another important implication that this paper brings up is related to the "Double Agency" issue. As we addressed in the paper, this is not a new concept. However, in our case, it has dramatic implications. Headhunters find candidates for clients, but they must sell clients to candidates. In what point is the right equilibrium of information about each party disclosed to the other? Clearly, the agency fiduciary role for the headhunter is with the client, but in some instance, they may have to push the client or candidate to make a final decision, in some cases exacerbating potential doubts. This is a field for further research, the ethics in this profession.

We want to emphasize that our propositions, beyond being part of the contributions of this paper, are more inclined to exemplify how this triadic relationship is heavily reliant on information asymmetries, along with some moral hazard and adverse selection. This reinforces our main idea that agency theory fits best when trying to explain the triad on which all parties play decisive roles.

We would like to point out that our research has three main limitations. First, regarding adverse selection in the executive recruitment process, we think this may be minimal. We base our arguments on two main situations: when a client decides to engage in an executive search process, the selection of the agent (headhunter) is based on previous experience and/or referrals, and therefore the information asymmetry tends to be partially offset. Also, if the outcome (candidate selection) is poor, there are some guarantees (for instance, replacing candidates, re-doing the whole process or waiving part of the professional fees). On the other hand, the adverse selection from the candidate's perspective is minimized by the information disclosed by the client and the headhunter during the process and, ultimately, by opting out of the selection or company (even after being hired, if needed). Therefore, we mainly focused our attention on the moral hazards instead of adverse selection. This may be an issue that could be addressed in the future.

The second limitation is the high level of confidentially in this sector (i.e., executive search firms). This has an important effect on the research of this topic. Notwithstanding this, more academic research about this service is warranted because it plays such an important role in many modern organizations.

Third, although we expressed early in the paper that information asymmetries were a main element in

BALDO, VALLE-CABRERA \& OLIVAS-LUJAN / DOI: 10.5929/9.1.6 
our research, we indeed addressed adverse selection and opportunism. However, we want to clarify that more detailed forms of "opportunism" in this relationship may be present and require future research.

\section{References}

Africa, M. F., \& Major, R. A., Jr. (1988). How employers can use headhunters effectively. Legal Economics, 14(1), 28.

Akerlof, G. A. (1970). The market for "lemons": Quality uncertainty and the market mechanism. Quarterly Journal of Economics, 84(3), 488-500.

Arrow, K. J. (1963). Uncertainty and the welfare economics of medical care. The American Economic Review, 53(5), 941-973.

Arrow, K. J. (1965). Aspects of the theory of risk-bearing. Helsinki: Yrjö Jahnssonin Säätiö.

Association of Executive Search and Leadership Consultants (AESC). (2011a). 2011 HR survey. New York, NY: Association of Executive Search and Leadership Consultants.

Association of Executive Search and Leadership Consultants (AESC). (2011b). AESC's 2011 senior executive recruitment survey the client speak. New York, NY: Association of Executive Search and Leadership Consultants.

Association of Executive Search and Leadership Consultants (AESC). (2014). 2014 state of the global retained executive search industry - part one. New York, NY: Association of Executive Search and Leadership Consultants (AESC).

Baker, T. (1996). On the genealogy of moral hazard. Texas Law Review, 75(2), 237-292.

Baldo, C. (2014). El perfil oculto del candidato ideal. Sobreponiéndose a la información asimétrica en búsquedas ejecutivas usando cazatalentos. [The ideal candidate's hidden profile. Overcoming asymmetric information on executive searches using headhunters]. Gestión y Gerencia, 8(2), 1-80.

Barney, J. (1991). Firm resources and sustained competitive advantage. Journal of Management, 17(1), 99-120.

Behrenz, L. (2001). Who gets the job and why? an explorative study of employers' recruitment behavior. Journal of Applied Economics, 4(2), 255-278.

Bidwell, M., \& Fernandez-Mateo, I. (2008). Three is a crowd? understanding triadic employment relationships. In P. Cappelli (Ed.), Employment relationships: New models of white collar work (pp. 142-178) Cambridge University Press New York.

Bloomberg Business. (2008a). List: Most influential headhunters, part one. Retrieved from http://www.bloomberg.com/bw/stories/2008-01-31/list-most-influential-headhunters-partonebusinessweek-business-news-stock-market-and-financial-advice

Bloomberg Business. (2008b). List: Most influential headhunters, part two. Retrieved from http://www.bloomberg.com/bw/stories/2008-10-28/list-most-influential-headhunters-parttwobusinessweek-business-news-stock-market-and-financial-advice

Breaugh, J. (1983). Realistic job previews: A critical appraisal and future research directions. The Academy of Management Review, 8(4), 612-619. 
Britton, L. C., \& Ball, D. (1999). Trust versus opportunism: Striking the balance in executive search. Service Industries Journal, 19(2), 132-149.

Britton, L. C., Wright, M., \& Ball, D. (2000). The use of co-ordination theory to improve service quality in executive search. The Service Industries Journal, 20(4), 85.

Bullhorn. (2014). North american staffing and recruiting trends report 2014. Boston: Bullhorn Inc.

Byrne, J. (1986). The headhunters (1st ed.). New York: MacMillan Publishing Company.

Carless, S. A. (2005). Person-job fit versus person-organization fit as predictors of organizational attraction and job acceptance intentions: A longitudinal study. Journal of Occupational and Organizational Psychology, 78(3), 411-429. DOI:10.1348/096317905X25995

Charan, R., Drotter, S., \& Noel, J. (2010). The leadership pipeline: How to build the leadership powered company John Wiley \& Sons.

Child, J., \& Rodrigues, S. (2003). Corporate governance and new organizational forms: Issues of double and multiple agency. Journal of Management \& Governance, 7(4), 337-360. DOI:10.1023/A:1026210608769

Clark, T., \& Salaman, G. (1998). Creating the 'right'impression: Towards a dramaturgy of management consultancy. Service Industries Journal, 18(1), 18-38.

Clark, T. (1993). The market provision of management services, information asymmetries and service quality - some market solutions: An empirical example. British Journal of Management, 4(4), 235.

Clerkin, T. A., \& Lee, J. -. (2010). Executive search relationships-contacts between executives and search firm professionals: Scale development and validation. Organisation Management Journal, 7(3), 208228.

Coverdill, J., \& Finlay, W. (1998). Fit and skill in employee selection: Insights from a study of headhunters. Qualitative Sociology, 21(2), 105-127.

Dingman, H. B. (1993). The right fit: Executive search by retained recruiters. Cornell Hotel and Restaurant Administration Quarterly, 34(6), 26.

Dzienkowski, J. S. (1992). Lawyers as intermediaries: The representation of multiple clients in the modern legal profession.

Eisenhardt, K. M. (1989). Agency theory: An assessment and review. Academy of Management. The Academy of Management Review, 14(1), 57.

Eriksson, S., \& Lagerström, J. (2006). Competition between employed and unemployed job applicants: Swedish evidence. Scandinavian Journal of Economics, 108(3), 373-396. DOI:10.1111/j.14679442.2006.00462.x

Evans, R. D., \& Kolbe, P. T. (2005). Homeowners' repeat-sale gains, dual agency and repeated use of the same agent. Journal of Real Estate Research, 27(3), 267-292.

Faulconbridge, J. R., Beaverstock, J. V., Hall, S., \& Hewitson, A. (2009). The 'war for talent': The gatekeeper role of executive search firms in elite labour markets. Geoforum, 40(5), 800-808.

Faulconbridge, J. R., Hall, S. J. E., \& Beaverstock, J. V. (2008). New insights into the internationalization of producer services: Organizational strategies and spatial economies for global headhunting firms.

BALDO, VALLE-CABRERA \& OLIVAS-LUJAN / DOI: 10.5929/9.1.6 
Environment and Planning A: Economy and Space, 40(1), 210-234. DOI:https://doi.org/10.1068/a3924

Finlay, W., \& Coverdill, J. (1999). The search game: Organizational conflicts and the use of headhunters. Sociological Quarterly, 40(1), 11-30.

Finlay, W., \& Coverdill, J. (2002). Headhunters matchmaking in the labor market (1st ed.). 2002: Cornell University Press.

Fish, A., \& Macklin, R. (2004). Perceptions of executive search and advertised recruitment attributes and service quality. Personnel Review, 33(1), 30-54.

Gardner, T. M., Stansbury, J., \& Hart, D. (2010). The ethics of lateral hiring. Business Ethics Quarterly, 20(3), 341-369.

Garrison, N. (2005). Headhunters and how to use them (1st ed.). London: Profile Books Ltd.

Greer, C. R., Youngblood, S. A., \& Gray, D. A. (1999). Human resource management outsourcing: The make or buy decision. The Academy of Management Executive (1993), 13(3), Themes: Teams and New Product Development), 85-96.

Groysberg, B., Sant, L., \& Abrahams, R. (2008). When 'stars' migrate, do they still perform like stars? MIT Sloan Management Review, 50(1), 41.

Gunawardane, G. (2012). Managing supplier to customer direct service triads in service supply chains - A case study. Journal of Supply Chain and Operations Management, 10(1), 50.

Guthridge, M., Komm, A. B., \& Lawson, E. (2008). Making talent a strategic priority. McKinsey Quarterly, (1), 48-59.

Hallock, K. F. (1999). Dual agency: Corporate boards with reciprocally interlocking relationships. Executive compensation and shareholder value (pp. 55-75) Springer.

Hamori, M. (2002). (2002). The role of clients in the executive search process. Paper presented at the Academy of Strategic and Organizational Leadership PROCEEDINGS, 29.

Hamori, M. (2004). Executive search and selection with mediation: The role of executive search firms in $\begin{array}{llll}\text { executive succession (Ph.D.). } & \text { (3138016). Retrieved from }\end{array}$ http://proquest.umi.com/pqdweb?did $=766277971 \&$ Fmt $=7 \&$ clientld $=47565 \&$ RQT $=309 \& V$ Name $=P$ $\underline{Q D}$

Hamori, M. (2010). Who gets headhunted - and who gets ahead? the impact of search firms on executive careers. Academy of Management Perspectives, 24(4), 46-59.

Heisler, J., Kallberg, J. G., \& Liu, C. H. (2007). The impact of dual agency. The Journal of Real Estate Finance and Economics, 35(1), 39-55.

Hines, A. H., Ader, D. N., Chang, A. S., \& Rundell, J. R. (1998). Dual agency, dual relationships, boundary crossings and associated boundary violations: A survey of military and civilian psychiatrists. Military Medicine, 163(12), 826-833.

Holmstrom, B. (1982). Moral hazard in teams. The Bell Journal of Economics, 13(1), 324-340.

Ibarra, H., \& Hunter, M. (2007). How leaders create and use networks. Harvard Business Review, 85(1), 40.

BALDO, VALLE-CABRERA \& OLIVAS-LUJAN / DOI: 10.5929/9.1.6 
Jamal, K., \& Bowie, N. E. (1995). Theoretical considerations for a meaningful code of professional ethics. Journal of Business Ethics, 14(9), 703-714.

Jensen, M. C., \& Meckling, W. H. (1976). Theory of the firm: Managerial behavior, agency costs and ownership structure. Journal of Finance Economics, 3(4), 303-431.

Jones, S. (1989). The headhunting business (1st ed.). London: The Macmillan Press LTD.

Khurana, R. (2001). Finding the right CEO: Why boards often make poor choices. MIT Sloan Management Review, 43(1), 91-95.

Khurana, R. (2002). Searching for a corporate savior: The irrational quest for charismatic CEO (1st ed.) Princeton University Press.

Kristof-Brown, A. L., Zimmerman, R. D., \& Johnson, E. C. (2005). Consequences of individuals'fit at work: A meta-analysis of person-job, person-organization, person-group, and person-supervisor fit. Personnel Psychology, 58(2), 281-342.

Malone, T. W., \& Crowston, K. (1990). (1990). What is coordination theory and how can it help design cooperative work systems? Paper presented at the Proceedings of the 1990 ACM Conference on Computer-Supported Cooperative Work, 357-370.

Miceli, T. J., Pancak, K. A., \& Sirmans, C. F. (2000). Restructuring agency relationships in the real estate brokerage industry: An economic analysis. Journal of Real Estate Research, 20(1), 31.

Miller, D. T. (1999). The norm of self-interest. American Psychologist, 54(12), 1053-1060. doi:10.1037/0003-066X.54.12.1053

Murphy, P. R., \& Poist, R. F. (1991). A comparison of headhunter and practitioner views regarding skill requirements of senior-level logistics professionals. Logistics and Transportation Review, 27(3), 277.

National Association of Executive Recruiters. (2014). Code of ethics. Retrieved from http://www.naer.org/code-of-ethics/

Ng, T. W., Eby, L. T., Sorensen, K. L., \& Feldman, D. C. (2005). Predictors of objective and subjective career success: A meta-analysis. Personnel Psychology, 58(2), 367-408.

Premack, S. L., \& Wanous, J. P. (1985). A meta-analysis of realistic job preview experiments. Journal of Applied Psychology, 70(4), 706-719. DOI:http://0-dx.doi.org.athenea.upo.es/10.1037/0021$\underline{9010.70 .4 .706}$

Rao, H., \& Drazin, R. (2002). Overcoming resource constraints on product innovation by recruiting talent from rivals: A study of the mutual fund industry, 1986-94. Academy of Management Journal, 45(3), 491-507. DOI:10.2307/3069377

Ross, S. A. (1973). The economic theory of agency: The principal's problem. The American Economic Review, 63(2), 134-139.

Rynes, S., \& Gerhart, B. (1990). Interviewer assessments of applicant 'fit': An exploratory. Personnel Psychology, 43(1), 13-13.

Seibert, S. E., Kraimer, M. L., \& Crant, J. M. (2001). What do proactive people do? A longitudinal model linking proactive personality and career success. Personnel Psychology, 54(4), 845-874. 
Seibert, S. E., Kraimer, M. L., \& Liden, R. C. (2001). A social capital theory of career success. Academy of Management Journal, 44(2), 219-237. DOI:10.2307/3069452

Sengupta, S. (2004). Delegating recruitment under asymmetric information. International Journal of Industrial Organization, 22(8-9), 1327-1347. DOI:10.1016/j.ijindorg.2004.03.006

Shapiro, S. P. (2005). Agency theory. Annual Review of Sociology, 31, 263-284.

Simmel, G. (1964). The sociology of Georg Simmel. (Vol. 92892). Simon and Schuster.

Simon, H. A. (1957). Models of man: Social and rational (1st ed.). New York: Wiley.

Sin, L. Y., Alan, C., \& Yim, F. H. (2005). CRM: Conceptualization and scale development. European Journal of Marketing, 39(11/12), 1264-1290.

Smith, A. (2010). The theory of moral sentiments. New York, NY: Penguin.

Stiglitz, J. E., \& Weiss, A. (1992). Asymmetric information in credit markets and its implications for macroeconomics. Oxford Economic Papers, , 694-724.

van de Valk, W., \& van Weele, A. (2011). (2011). Business service triads: A new area for service research. Paper presented at the IPSERA 2011 Conference Proceedings, 978-994.

Vandenberg, R. J., \& Nelson, J. B. (1999). Disaggregating the motives underlying turnover intentions: When do intentions predict turnover behavior? Human Relations, 52(10), 1313-1336.

Volpe, L., \& Tucker, J. (2004). Third-party recruiting. Employment Relations Today, 31(1), 1.

Werr, A., \& Pemer, F. (2007). Purchasing management consulting services-From management autonomy to purchasing involvement. Journal of Purchasing and Supply Management, 13(2), 98-112. DOI:http://0-dx.doi.org.athenea.upo.es/10.1016/j.pursup.2007.05.003

Williamson, O. E. (1981). The economics of organization: The transaction cost approach. American Journal of Sociology, 87(3), 548-577.

Williamson, O. E., Wachter, M., \& Harris, J. (1975). Understanding the employment relation - the analysis of idiosyncratic exchange. Bell Journal of Economics, 6(1), 250.

About the Authors

Carlos Baldo (cbaldo@coloradomesa.edu) is an Assistant Professor of Management at Colorado Mesa University. His research focus on Executive Search Firms, Agency Theory in triadic relationships, and Recruitment \& Selection. Prior to entering academia, he worked 12 years in multiple companies including some MNCs.

Ramón Valle-Cabrera (rvalcab@upo.es) is a Professor of Human Resource Management in the Business Administration Department, Universidad Pablo de Olavide (Seville, Spain). His teaching and research interests focus on strategic human resource management and innovation. He is heading several research projects on innovation, organizational capital, and employment relationships, and he is co-author of several HRM textbooks and papers in international journals.

Miguel Olivas-Lujan (molivas@clarion.edu) is a Professor at Clarion University of Pennsylvania. He researches careers, diversity, ethical decision-making, and information technologies. His work has appeared in four languages and has been presented in all inhabited continents; he co-edits the Advanced Series in Management.

BALDO, VALLE-CABRERA \& OLIVAS-LUJAN / DOI: 10.5929/9.1.6 